\title{
Synchrotron FTIR Light Reveals Signal Changes of Biofunctionalized Magnetic Nanoparticle Attachment on Salmonella sp.
}

\author{
Jaravee Sukprasert, ${ }^{1}$ Kanjana Thumanu, ${ }^{2}$ Isaratat Phung-on, ${ }^{3}$ Chalermkiat Jirarungsatean, ${ }^{3}$ \\ Larry E. Erickson, ${ }^{4}$ Pravate Tuitemwong ${ }^{\mathbb{D}},{ }^{1,5}$ and Kooranee Tuitemwong ${ }^{6}$ \\ ${ }^{1}$ Bioscience Program, Department of Microbiology, King Mongkut's University of Technology Thonburi (KMUTT), \\ Bangkok 10140, Thailand \\ ${ }^{2}$ Synchrotron Light Research Institute (Public Organization), Muang District, Nakhonratchasima 30000, Thailand \\ ${ }^{3}$ Maintenance Technology Center, Institute for Scientific and Technological Research and Services (ISTRS), KMUTT, \\ Bangkok 10140, Thailand \\ ${ }^{4}$ Chemical Engineering, Kansas State University, Manhattan, KS 66506, USA \\ ${ }^{5}$ Food Safety Center, ISTRS, KMUTT, Bangkok, Thailand \\ ${ }^{6}$ Department of Microbiology, Faculty of Science, Kasetsart University, Bangkok 10900, Thailand
}

Correspondence should be addressed to Pravate Tuitemwong; ptt59@hotmail.com and Kooranee Tuitemwong; fscikrt@ku.ac.th

Received 3 March 2020; Revised 12 May 2020; Accepted 25 May 2020; Published 29 June 2020

Academic Editor: Lucien Saviot

Copyright (c) 2020 Jaravee Sukprasert et al. This is an open access article distributed under the Creative Commons Attribution License, which permits unrestricted use, distribution, and reproduction in any medium, provided the original work is properly cited.

\begin{abstract}
The objective of this research was to develop new technology for possible noncontact, nondestructive, and culture-independent rapid detection of Salmonella using ferromagnetic nanoparticles. Light signal changes of particles, cells, and their reaction stages were investigated. Amino-functionalized ferromagnetic nanoparticles (amino-FMNs) were synthesized and modified by glutaraldehyde to crosslink the attachment of specific antibodies to the particles. The nanoparticle complex was used to capture, concentrate, and isolate Salmonella in a culture broth. Signal changes of the four stages of the nanoparticles-aminoglutaraldehyde-antibodies-Salmonella cell attachments were tracked with sensitive Synchrotron FTIR spectroscopy (SR-FTIR). The unique peaks from these four steps were identified. Results can be applied to develop a new test method or a new test/universal reader for rapid, nondestructive, and culture-independent detection of Salmonella in food products using IR spectroscopy at wave numbers $1454 \mathrm{~cm}^{-1}, 1542 \mathrm{~cm}^{-1}$, and $1414 \mathrm{~cm}^{-1}$, respectively.
\end{abstract}

\section{Introduction}

Foodborne diseases are important public health problems worldwide. Salmonella is one of the four key pathogenic bacteria that are the main causes of diarrheal diseases throughout the world [1]. The US Centers for Disease Control and Prevention (CDC) estimates 1.2 million cases of foodborne illnesses, 23,000 hospitalizations, and 450 deaths every year in the United States due to infection with Salmonella [2]. In Europe, as reported by the European Food Safety Authority
(EFSA) and European Centre for Disease Prevention and Control (ECDC) in 2017 [3], Salmonella was the commonest detected cause of reported outbreaks of foodborne infection and caused 91,662 illnesses in the European Union. The published data suggested that egg, meat, and meat products were the highest risk agents/food pairs [3]. In Thailand, the Bureau of Epidemiology, Department of Disease Control, Ministry of Public Health, reported 115,095 cases of foodborne illnesses in 2018, and Salmonella is one of the top three agents in food contaminated by pathogenic microorganisms [4]. Salmonella 
is a gram-negative and rod-shaped bacillus, which belongs to the family Enterobacteriaceae [5, 6]. More than 2,500 serotypes of Salmonella have been reported $[7,8]$. Of these, Salmonella enterica serovar Typhimurium ( $S$. Typhimurium) and S. enterica serovar Enteritidis ( $S$. Enteritidis) are the most common serotypes associated with human illness, and detection of Salmonella in food products is very important for the effective prevention of severe health problems.

Standard methods currently used for Salmonella detection in food samples such as ISO 6579:2002 and US FDABAM methods have several steps including selective/nonselective enrichments to increase the number of the target microorganism, selective plating for isolation, and biochemical and serological tests for confirmation. These methods are laborious and time-consuming and require 4 to 7 days to complete $[7,8]$.

Culture-independent methods could dramatically overcome the time-consuming culturing steps. Nondestructive and noncontact rapid detection is essential to ease detection and avoid contamination in laboratories. It also allows high-throughput testing and increases sample size $(n)$. Recently, nanoparticles have been used for various applications including protein immobilization, bioseparation, environmental treatment, biomedical and bioengineering usage, and food analysis [9]. Among all types of nanoparticles, magnetic nanoparticles (MNPs), especially magnetite $\left(\mathrm{Fe}_{3} \mathrm{O}_{4}\right)$ and maghemite $\left(\gamma-\mathrm{Fe}_{2} \mathrm{O}_{3}\right)$ nanoparticles, are of interest in various chemical and biological applications such as catalysis, magnetic hyperthermia, magnetic resonance imaging (MRI), bioseparation, diagnostic agents, biomolecule immobilization, drug delivery, and bacteria detection [9-11]. Magnetite ( $\mathrm{Fe} 3 \mathrm{O} 4)$ and maghemite $\left(\gamma-\mathrm{Fe}_{2} \mathrm{O}_{3}\right)$ nanoparticles are useful because of their unique properties such as superparamagnetism, high surface areas, large surface-to-volume ratio, low toxicity, and ease of separation under external magnetic fields [9, 12]. Several methodologies were reported using magnetic nanoparticles in combination with other materials or other methods such as with silica nanoparticles, polymerase chain reaction (PCR), or cultural isolation methods [11, 13-15].

Different types of nanoparticles (NPs) including, silica, gold, silver, and magnetic NPs have been used for direct bacteria detection and screening. Detection techniques that use NPs for the capture of foodborne pathogens are rapid, sensitive, and specific [16].

The binding affinity between the target pathogen and NPs in detection methods depends on the immobilization of the NPs with the specific recognition elements such as antibodies, biological molecules, and aptamer. The specific bioconjugation with target microbes improves the NP adsorption to pathogens [17].

Gold nanoparticles (AuNPs) offer unique optical properties that could provide color-changing property under aggregation-induced interparticle surface plasmon resonance or electron oscillation with light. The assay has a visible color change from red to blue (violet) that can be seen by the naked eye. AuNP binding to E. coli O157:H7 gives a color change from red to blue in a sample solution due to $E$. coli O157:H7 bindings and the specific antibody [18].
Fourier-transform infrared (FTIR) spectroscopy is a powerful rapid nondestructive analytical technique [19] that is sensitive and versatile [20]. This technique is a measurement of the vibration properties of chemical bonds when excited by the absorption of IR radiation in a sample [21]. Biological applications include detection, discrimination, classification of bacteria [22], protein structural studies [23], diagnosis of breast cancer [24], and investigation of biological tissues [25]. This method could be used as a test method, but the cost of the machine was high. Alternatively, the FTIR method was used to identify unique peaks for future machine design and other culture-independent applications.

The detection and identification of pathogenic organisms by spectroscopic techniques give a great benefit and value to the quantitative and qualitative information of the target pathogens. It is a promising method because of their sensitivity, rapidity, and low expenses and simplicity [26]. In this case, the unique peaks for all bacteria tested (Bacillus megaterium, Escherichia coli, and Pseudomonas stutzeri) that were missing in fungi were the peak at wave number 1396. On the other hand, fungi (Penicillium sp., Memnoniella sp., and Fusarium sp.) had a unique peak at wave number 1377 that was absent in all bacteria tested. The technique was suggested to be used for rapid discrimination between bacterial and fungal infections and contaminations.

FTIR techniques could be used to identify and classify bacterial strains through the use of the spectral library for each type of bacteria [27]. Further applications of FTIR spectroscopy as a bacterial source tracking tool are to discriminate fecal Escherichia coli strains from cows, chickens, and humans. The application of specific peaks unique to different strains or species of bacteria is promising and worth further investigation [21]. FTIR spectra in the region between 2861 and $3026 \mathrm{~cm}^{-1}$ were suggested as suitable unique peaks for fecal E. coli discrimination. They were peaks at wave numbers 2852 of C-H stretching of $\mathrm{CH}_{2}$ in fatty acid, 2924 and 2946 for $\mathrm{C}-\mathrm{H}$ stretching of $\mathrm{CH}_{2}$, and 2960 for C-H stretching of $\mathrm{CH}_{3}$ in fatty acids. The identification of structural changes in molecular binding between microorganisms and metal atoms of nanoparticles was reported by [28]. FTIR spectra changes in the fatty acids, specifically - $\mathrm{CH}$ deformation, to alter bacterial membrane permeability, due to the interaction of cells to AgNPs were reported.

The infrared spectrum of compounds and their interactions also give a unique fingerprint for microbial identification [29]. FTIR spectroscopy could be used as a unified method for the analysis of many cellular metabolites for the screening of microbial bioprocesses [30]. The tracking of pharmacological substances is also reported [31]. The observation indicates the versatility of FTIR tracking in dynamic and sequential reactions such as the attachment of pathogens to target cells or supporting materials [28].

Synchrotron radiation-based FTIR (SR-FTIR) spectroscopy has an advantage for these experiments due to its higher signal-to-noise ratio (by 100- to 1000-fold), higher collimation, and luminance, which can reach diffraction limit with $10 \mu \mathrm{m}$ or better compared with conventional FTIR with about $75 \mu \mathrm{m}$ spatial resolution [32]. 
The objective of this research was to develop new technology by employing the Synchrotron FTIR light to track signal changes of attachment/reaction steps of the particles, crosslinker, antibody, and Salmonella cells. This was to identify unique peaks of each reaction step that enable further development of effective rapid, noncontact, and cultureindependent detection platforms for Salmonella in foods and other applications for food and environmental and medical diagnosis in the future.

\section{Materials and Methods}

2.1. Preparation of Magnetic Nanoparticles. Preparation of magnetic nanoparticles (amino-FNPs) using the polyol technique with ethylenediamine as the amino group source was described by Songvorawit et al. [11]. Briefly, $2 \mathrm{~g}$ of ferric chloride $\left(\mathrm{FeCl}_{3} \cdot 6 \mathrm{H}_{2} \mathrm{O}\right)$ was dissolved in $40 \mathrm{ml}$ ethylene glycol and mixed until the solution was clearly yellow. Then, $6 \mathrm{~g}$ of sodium acetate $\left(\mathrm{CH}_{3} \mathrm{COONa}\right), 1.68 \mathrm{~g}$ of sodium hydroxide $(\mathrm{NaOH})$, and $20 \mathrm{ml}$ of ethylenediamine were added and stirred for $30 \mathrm{~min}$. After mixing, the solution was further heated in an autoclave at $121^{\circ} \mathrm{C}, 105 \mathrm{kPa}$, and $2 \mathrm{~h}$ per cycle for 3 cycles. After each cycle, the mixed solution was shaken for 5 min to complete the reaction. After completion, the aminofunctionalized ferromagnetic nanoparticles (amino-FMNs) were separated by magnet and washed five times with deionized water and five times with $95 \%$ ethanol to remove the solvent. Ultrasonication was used while washing to remove the solvent from the particle surface. The MNPs were dried in an oven at $50^{\circ} \mathrm{C}$ for $24 \mathrm{~h}$, milled with mortar, and kept in airtight amber bottles until use.

2.2. Surface Modification of Magnetic Nanoparticle with Glutaraldehyde. Glutaraldehyde (GA) was used as the crosslinker to connect antibodies to the nanoparticle surface. The aldehyde group reacts with amino-FMN, while the aldehyde group on the other end could link to amine groups of the antibodies [33]. The reaction was used to improve the immobilization capacity of antibodies [34]. For the reaction, firstly, $0.1 \mathrm{~g}$ of MNPs was washed and resuspended in $50 \mathrm{ml}$ of phosphate-buffered saline (PBS) $\mathrm{pH} 7.4$ at a concentration of $2 \mathrm{mg} / \mathrm{ml}$. Then, $5 \mathrm{ml}$ of glutaraldehyde $(25 \% \mathrm{v} / \mathrm{v})$ was added and stirred at room temperature for $2 \mathrm{~h}$. The modified MNPs were separated by an external magnetic field and washed three times with PBS ( $\mathrm{pH} 7.4)$ to remove free glutaraldehyde. It was resuspended in PBS before being used in the next step [11].

\subsection{Preparation of Antibody- (Ab-) Conjugated Magnetic} Nanoparticle. The antibody Salmonella enterica serotype Typhimurium: 1,4,[5],12 i:1,2 was used in this study. The strain has the $\mathrm{O}$ antigen factors $[1,4,[5]$, and 12 , the flagella $\mathrm{H}$ antigen $\mathrm{i}\left(1^{\text {st }}\right.$ phase), and the flagella $\mathrm{H}$ antigens 1 and 2 ( $2^{\text {nd }}$ phase).

Glutaraldehyde-modified FMNs were conjugated with the polyclonal antibody against Salmonella Typhimurium (S\&A Reagents Lab, Bangkok, Thailand) and incubated at $25^{\circ} \mathrm{C}$ overnight with gentle shaking. Then, the particles were washed three times with $1 \mathrm{x}$ PBS ( $\mathrm{pH} 7.4)$ to remove free che- micals and antibodies. They were stored in an air-tight amber bottle at $4^{\circ} \mathrm{C}$ until use.

\subsection{Attachment of Antibody-Conjugated Magnetic} Nanoparticles to Salmonella Cells. The antibody-conjugated magnetic nanoparticles were reacted with Salmonella Typhimurium cells by mixing $500 \mu \mathrm{l}$ of cell suspension with $8 \mu \mathrm{l}$ of the magnetic nanoparticles and incubating at $37^{\circ} \mathrm{C}$ for $30 \mathrm{~min}$ in a shaker incubator. After that, the particle-bacterial complexes were separated from the suspension by a magnet. At each preparation step, samples were washed three times with PBS ( $\mathrm{pH} \mathrm{7)} \mathrm{buffer} \mathrm{to} \mathrm{wash} \mathrm{away} \mathrm{free} \mathrm{glutaraldehyde}$ and antibodies. The particles and cells, after attachment steps, were analyzed with Synchrotron radiation-based Fourier-transform infrared (SR-FTIR) spectroscopy and field emission scanning electron microscopy (FESEM) techniques. The unique peaks of each step were identified. The particle-bacterial complexes were determined for capture efficiency of Ab-conjugated FMNs by plating for enumeration on xylose lysine desoxycholate agar (XLD) and incubated at $37^{\circ} \mathrm{C}$ for $48 \mathrm{~h}$.

2.5. Synchrotron FTIR (SR-FTIR) Spectroscopy Detection of Signal Changes. SR-FTIR signal changes of reaction steps of amino-FMNs, glutaraldehyde (GA), Salmonella cells, antibody alone, and their attachment steps were monitored in duplicate. Five (5) $\mu \mathrm{l}$ of each sample was dropped onto barium fluoride windows, spread very thinly from the droplet in a linear fashion on the slide surface using pasture pipette, and then vacuum-dried for $30 \mathrm{~min}$ in a desiccator. Four (4) spots per window were prepared for the signal change tracking.

FTIR experiments were conducted at the IR station of the Synchrotron Light Research Institute (Public Organization), Thailand. Samples were analyzed in the transflection mode, using the conventional internal IR source of a Bruker Vertex 70 spectrometer connected to the Bruker Hyperion 2000 microscope (Bruker Optics Inc., Ettlingen, Germany). The microscope with a 36x objective/condenser was equipped with a nitrogen-cooled MCT $(\mathrm{HgCdTe})$ detector (area $250 \times$ $250 \mu \mathrm{m}^{2}$ ). For each measurement, IR signals were acquired from $20 \times 20 \mu \mathrm{m}^{2}$ aperture size, mapped within most homogeneous zones. Sixty-four scans $\left(20 \mathrm{kHz}\right.$ velocity and $4 \mathrm{~cm}^{-}$ ${ }^{1}$ spectral resolution) were performed within the $4000-800 \mathrm{~cm}^{-}$ ${ }^{1}$ spectral interval to obtain the average spectra with an appropriate signal-to-noise ratio. This would provide sufficient repeatable information for each spectrum.

Since there were a number of cells analyzed from one set of measurements within the aperture area, several locations were selected for the spectra of each interested cell. Then, from the reproducible spectra measured from several cells, the OPUS 6.5 software (Bruker) was implemented to combine all spectra readily for further comparison with other sets of measurements or experiments.

2.6. Bacteria Imaging under FESEM Microscopy. Field emission scanning electron microscopy (FESEM) that used electron, liberated by a field emission source, in place of light in a zig-zag pattern, was used to scan Salmonella cells with 
and without FMN attachments. For sample preparation, the bacteria were washed three times in phosphate-buffered saline (PBS, pH 7.2) for 15 min each and left in $2.5 \%$ glutaraldehyde and PBS for $12 \mathrm{~h}$. Samples were washed three times with PBS, then exposed in a series $(25 \%, 50 \%, 75 \%, 90 \%$, and $100 \%$ ) of ethanol solutions for 20 min each to dehydrate cells. Finally, the samples were critical point-dehydrated (CHRIST Beta2-8 LCS plus 102125, Germany) using carbon dioxide as the transition fluid and coated with gold and palladium sputtering (Quorum, SC7620, UK). High-magnification imaging of the FMNs attached with Salmonella cells was performed at an operating voltage of $5 \mathrm{kV}$ under the FESEM (TESCAN, MIRA 3, Czech Republic).

\section{Results}

3.1. Tracking of Signal Changes of Magnetic Nanoparticles Attached to Salmonella Cells. This technology development is aimed at tracking signal changes of the attachment steps of FMN particles to the GA crosslink, antibodies, and Salmonella for further development methods for the rapid detection of Salmonella spp. In this study, the amino-FMN particle surface was modified with glutaraldehyde crosslink. Antibodies against Salmonella spp. were attached to glutaraldehyde that enables the nanoparticles to attach onto Salmonella cells. Signal changes at each stage were tracked with SR-FTIR spectroscopy as illustrated in Figure 1.

\subsection{SR-FTIR Spectra of Amino-FMNs, Glutaraldehyde, Salmonella Cells, and Antibody}

3.2.1. Amino-FMNs. The amino-FMNs were black in color and could be attracted by an external magnetic force (Figure 2(a)). The size and morphology of FMNs were investigated by FE-SEM (Figure 2(b)). The cubic nanoparticles had uniform particle size. The average diameter of the nanoparticles determined by FE-SEM was approximately $50 \mathrm{~nm}$.

SR-FTIR spectra of individual GA, Salmonella cell, amino-FMNs, and antibody against Salmonella cells are displayed in Figure 3. The peak at $1673 \mathrm{~cm}^{-1}$ corresponded well with $\mathrm{N}-\mathrm{H}$ scissoring vibration of $\mathrm{NH}_{2}$ in aliphatic primary amine [28]. It is a characteristic of a single amino-FMN particle. Results indicated the existence of an amino group on the particle surface.

3.2.2. Glutaraldehyde (GA). The absorption characteristics of glutaraldehyde alone showed carbonyl groups of aldehyde (-CHO) absorption at $1722 \mathrm{~cm}^{-1}$ and $\mathrm{C}-\mathrm{H}$ stretching of aldehyde (-CHO) absorption at wave number 2872 . They were the FTIR spectrum characteristic of glutaraldehyde. The presence and absence of these peaks were used to indicate an interaction with FMNs and antibodies.

3.2.3. Antibody against Salmonella. Figure 4(c) and Table 1 showed the FTIR spectrum of antibody against Salmonella that demonstrated a characteristic of serum antibodies in the protein region with main peaks at $1656 \mathrm{~cm}^{-1}(\mathrm{C}=\mathrm{O}$ stretching vibration of amide I band) and $1545 \mathrm{~cm}^{-1}$ (C-N stretching and $\mathrm{N}-\mathrm{H}$ bending vibration of amide II band).
3.2.4. Salmonella Cells. Synchrotron FTIR spectra of Salmonella cells alone are shown in Figure 3. FTIR spectroscopy could identify variations in the total composition of bacterial cells, including protein, fatty acids, nucleic acid, and carbohydrate, due to functional group vibrations in the main biomolecular constituents [19]. The main region to analyze components of intact bacterial cells followed that indicated by Naumann [35]. The region between 3000 and $2800 \mathrm{~cm}^{-1}$ was fatty acid and lipid regions. Peaks between 1800 and $1500 \mathrm{~cm}^{-1}$ were amide I and amide II of proteins and peptides, the region from 1500 to $1200 \mathrm{~cm}^{-1}$ was a phospholipid/DNA/RNA region, and the region in $1200-900 \mathrm{~cm}^{-1}$ was for carbohydrate. Moreover, the region from 900 to 600 was ascribed as a fingerprint region [35].

Figure $3(\mathrm{~d})$ showed bands at $2876 \mathrm{~cm}^{-1}$ of $-\mathrm{CH}$ symmetric stretching of $\mathrm{CH}_{2}$ in fatty acids, respectively $[19,35]$. The peak at $3287 \mathrm{~cm}^{-1}$ indicates $\mathrm{N}-\mathrm{H}$ stretching of amide A and amide $B$, respectively, in protein [16]. Besides, the majority of responsible peaks for the protein region were observed at 1654 and $1544 \mathrm{~cm}^{-1}$, which are dominated by the amide I and amide II of proteins and peptide. The regions between the 1500 and $1200 \mathrm{~cm}^{-1}$ area were the fatty acid region. The observed peaks around 1451, 1406, and $1238 \mathrm{~cm}^{-1}$ were $\mathrm{CH}_{2}$ scissoring vibration [36], $\mathrm{C}=\mathrm{O}$ symmetric stretching of $\mathrm{COO}^{-}$group, and $\mathrm{P}=\mathrm{O}$ asymmetric stretching of phosphodiester in phospholipids, respectively [19]. The band at $1086 \mathrm{~cm}^{-1}$ was dominated by $\mathrm{C}-\mathrm{O}-\mathrm{C}$ and $\mathrm{C}-\mathrm{O}$ ring vibration in various polysaccharides. In the region between wave number 900 and $600 \mathrm{~cm}^{-1}$ is the fingerprint region that corresponds to nucleic acids, i.e., phenylalanine, tyrosine, tryptophan, and various nucleotides [35].

3.3. SR-FTIR Spectra of FMNs-Glutaraldehyde- (GA-) Antibodies- (Ab-) Salmonella Complex. Figure 4 shows the SR-FTIR spectra of the 4 reaction steps of FMN attachment to GA, antibody, and Salmonella cells. In Figure 4(a), SRFTIR spectra of the FMNs-GA-Ab complex displayed a sharp absorbance at $1652 \mathrm{~cm}^{-1}$ ascribing to $\mathrm{C}=\mathrm{O}$ stretching, which is a characteristic of amide I band, and the peak around $1547 \mathrm{~cm}^{-1}$, a characteristic of amide II band with C-N stretching and $\mathrm{N}-\mathrm{H}$ bending $[37,38]$. Both peaks indicated the attachment of antibodies to the particle surface $\left(\mathrm{NH}_{2}\right.$ FMN). Results indicated the successful attachment of glutaraldehyde to add amine groups onto the surface of FMNs and, on another end, to the amine of antibody conjugation to form amide bonding (-CONH-) [33].

FTIR spectroscopy of the interaction of the nanoparticle complex to Salmonella cells is shown in Figure 4(b). The spectra incorporated not only the protein peaks at 1649 and $1542 \mathrm{~cm}^{-1}$, assigned to amide I of $\alpha$-helical structures of proteins and amide II band of proteins [19], but also the presence of peaks due to carbohydrates, lipid, and glycoprotein at peaks between $1454 \mathrm{~cm}^{-1}$ of $\mathrm{CH}_{2}$ bending lipids $[22,36]$ and $1414 \mathrm{~cm}^{-1}$ due to $\mathrm{C}=\mathrm{O}$ symmetric stretching of the $\mathrm{COO}^{-}$group in amino acids and fatty acids [19].

3.4. Confirmation of Attachments under FE-SEM Imaging. The attachment of the FMN-Ab complex on the cell surface 


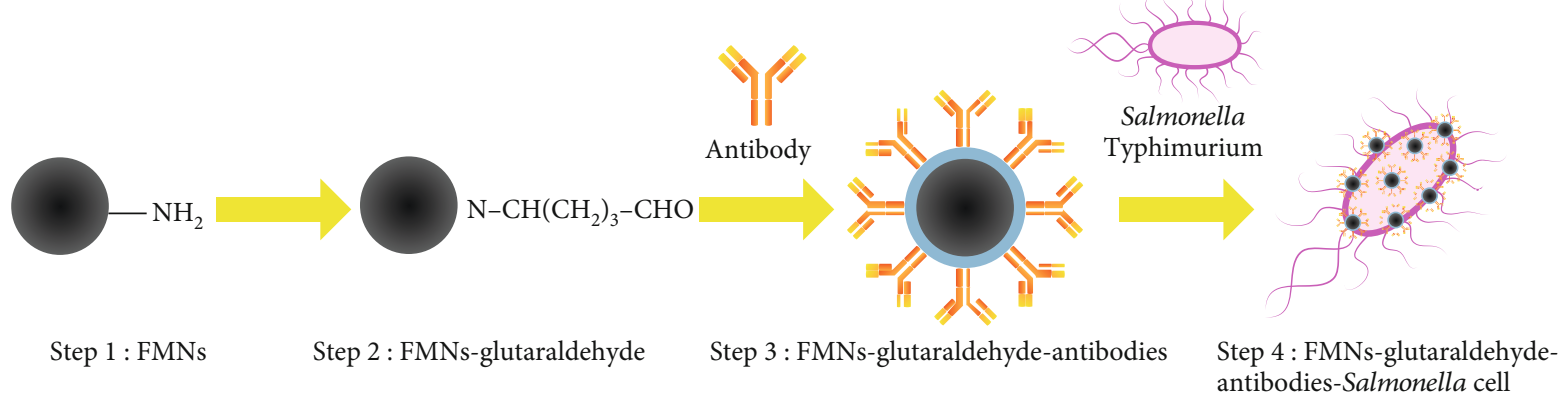

Figure 1: Schematic diagram of the designed experiment to assess with FTIR spectra of each reaction step.

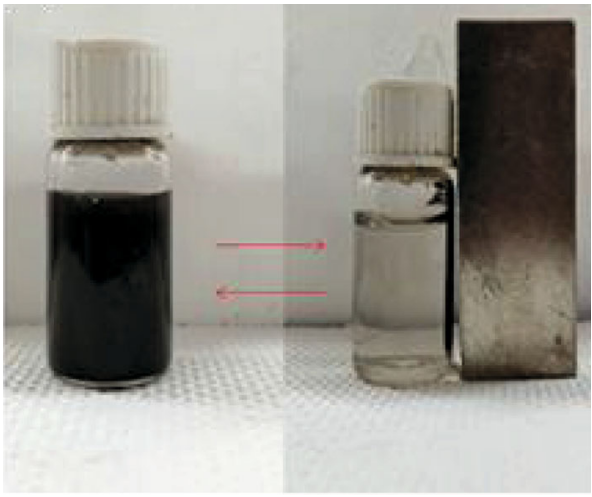

(a)

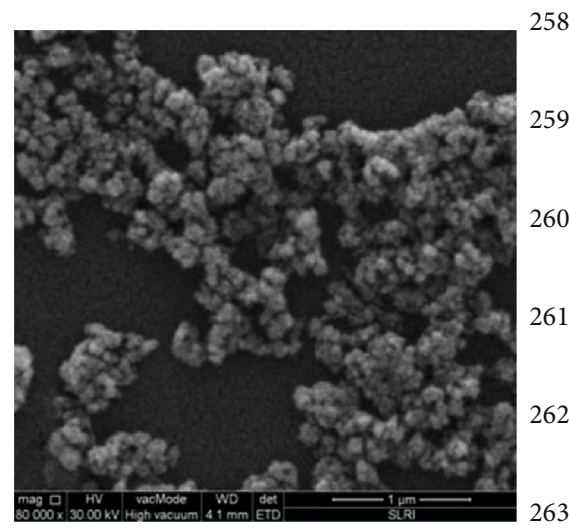

(b)

FIgure 2: Amino-FMN particles could be attracted by a magnet. The FE-SEM image shows cubic shape nanoparticles of about $50 \mathrm{~nm}$ diameter. The scale in (b) is $1 \mu \mathrm{m}$.

of a Salmonella cell was confirmed by FE-SEM as shown in Figures 5(a) and 5(b). The complex could form colonies on xylose lysine desoxycholate agar (XLD) as shown in Figure 5(c). It demonstrated Salmonella viability after the attachment of the FMN complex.

\section{Discussion}

The hypothesis of this research was to identify the unique peaks of each reaction steps of FMN nanoparticle and Salmonella cells. The characteristics of MNPs were reported elsewhere by our laboratory [11]. The cubic MNPs were ferromagnetism and very close to complete superparamagnetism with a saturation magnetization (Ms) of about $48 \mathrm{emu} / \mathrm{g}$, remanence $(\mathrm{Mr})$ of $1.7 \mathrm{emu} / \mathrm{g}$, and coercivity $(\mathrm{Hc})$ of 23.5 Oe. The MNPs were well dispersed in water and could be separated from the solution by the attraction of a magnet.

Amino-functionalized ferromagnetic nanoparticle surface modification was made to allow further attachment of specific antibodies. The surfaces of magnetic nanoparticles were modified with glutaraldehyde crosslink. Antibodies against Salmonella spp. were attached to the aldehyde group of the other end of glutaraldehyde. The antibodies allowed the nanoparticle complexes to attach onto Salmonella cells. In this study, each stage was tracked with SR-FTIR spectroscopy. The spectra of each stage are shown in Figure 4. FTIR spectroscopy is a method based on the measurement of vibration of a molecule excited by IR radiation at a specific wavelength range $[19,21]$. The mid-IR $\left(400-4000 \mathrm{~cm}^{-1}\right)$ is the most commonly used region for analysis as all molecules possess characteristic absorbance frequencies and primary molecular vibrations in this range [19]. This method is a sensitive, quick, and noninvasive technique [32]. Synchrotron radiation FTIR (SR-FTIR) spectroscopy was used in this study because of its high signal-to-noise ratio (by 100- to 1000-fold), high collimation, and luminance, which can reach the diffraction limit with $10 \mu \mathrm{m}$ or better compared with conventional FTIR spectroscopy. With this capacity, it could probe the heterogeneities in the bacteria at a single cell level [32].

Characterization of unique peaks for control and test peaks.

The SR-FTIR spectra were obtained from materials and their 4 reaction stages as follows:

Stage I: controls: amino-functionalized FMN, glutaraldehyde, antibodies, and Salmonella cells alone

Stage II: FMN with surface modification and GA crosslinking

Stage III: FMN-GA with antibodies

Stage IV: FMN-GA-antibody complex with Salmonella cells

4.1. Stage I: Controls-Amino-Functionalized FMN, Glutaraldehyde, Antibodies, and Salmonella Cells. Preparation 


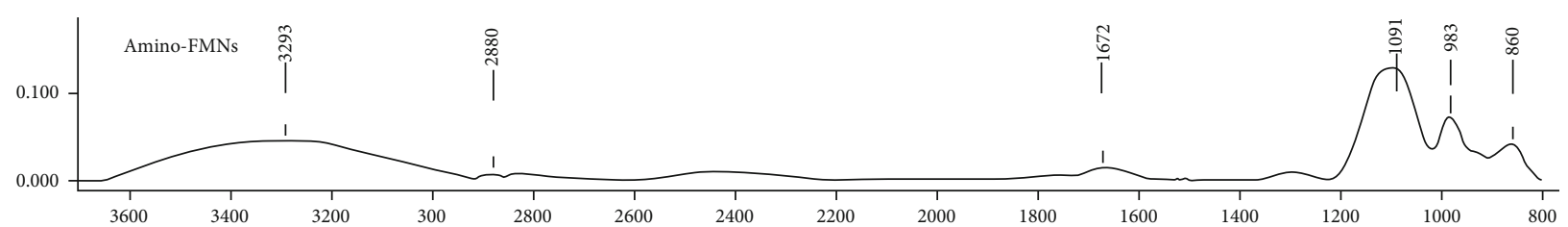

(a)

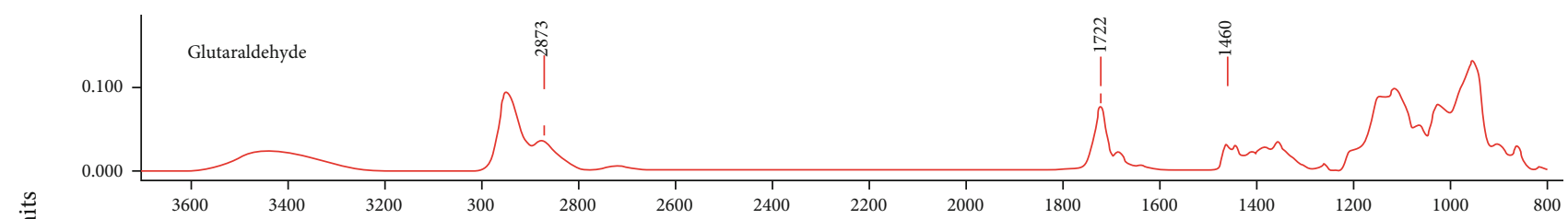

(b)

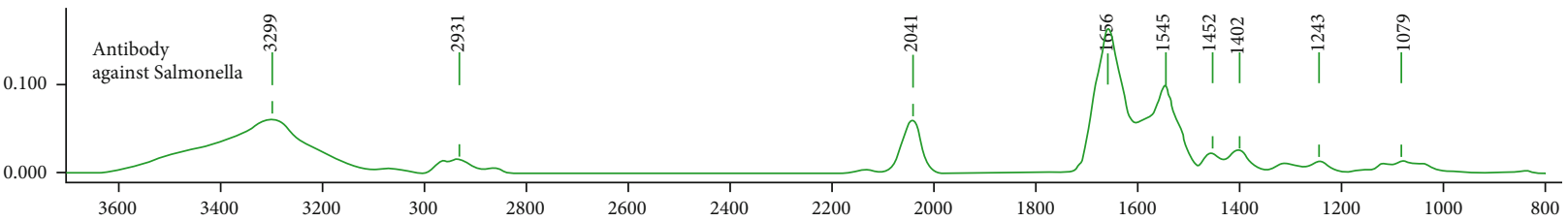

(c)

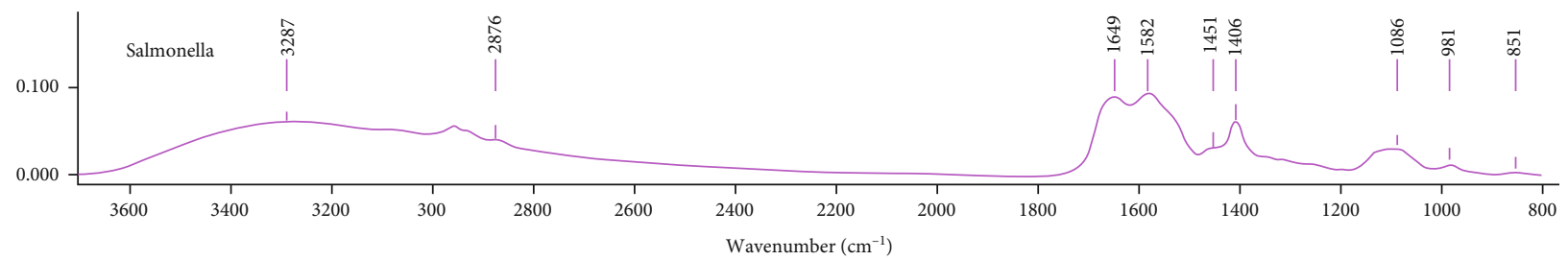

(d)

FIGURE 3: Synchrotron FTIR spectra of amino-functionalized magnetic particle FMNs (a) glutaraldehyde (b), antibody against Salmonella (c), and Salmonella cell with a unique peak at wave number 1451 (d).

of magnetic nanoparticles (amino-functionalized FMN) employed the polyol technique using ethylenediamine as an amino group source $\left(-\mathrm{NH}_{2}\right)$. The chemical formula of ethylenediamine is $\mathrm{NH}_{2} \mathrm{CH}_{2} \mathrm{CH}_{2} \mathrm{NH}_{2}$, and there was the functional group including amino $\left(-\mathrm{NH}_{2}\right)$ and $\mathrm{CH}_{2}$ groups. The main SR-FTIR peaks obtained from amino-functionalized FMN can be assigned as follows: $3293 \mathrm{~cm}^{-1}$ (O-H stretching), $2881 \mathrm{~cm}^{-1}$ (C-H asymmetric stretching of $\mathrm{CH}_{2}$ in aliphatic compounds), $2810 \mathrm{~cm}^{-1}$ (C-H symmetric stretching of $\mathrm{CH}_{2}$ in aliphatic compounds) $[39,40], 1673 \mathrm{~cm}^{-1}$ (N-H bending (scissoring) vibration of $\mathrm{NH}_{2}$ in aliphatic primary amines) $[37,40], 1090 \mathrm{~cm}^{-1}$ (C-N stretching), $983 \mathrm{~cm}^{-1}$ (C-H out of plane bending of $\mathrm{CH}_{2}$ ), and $858 \mathrm{~cm}^{-1}(\mathrm{~N}-\mathrm{H}$ out of plane bending of $\mathrm{NH}_{2}$ ) [37, 40] (Table 1; Figures 3 and 4). However, the vibrational modes ascribed to the amino group appeared especially the band at $1673 \mathrm{~cm}^{-1}$ and $858 \mathrm{~cm}^{-1}$, while the characteristic absorption of $\mathrm{CH}_{2}$ was observed at $2881 \mathrm{~cm}^{-1}$ and $983 \mathrm{~cm}^{1}$, respectively. Furthermore, the C-N stretching appeared at $1090 \mathrm{~cm}^{-1}$, which is the core of the chemical structure of ethylenediamine. As discussed above, it clearly indicated the presence of ethylenediamine on the surface of nanoparticles. The characteristic peak on the spectrum of amino-functionalized FMNs appeared at $1673 \mathrm{~cm}^{-1}$ from N$\mathrm{H}$ scissoring of $\mathrm{NH}_{2}$, which is a unique peak for control of stage I. Glutaraldehyde exhibited unique peaks at wave num- bers 1722 and 1460 of $\mathrm{C}=\mathrm{O}$ stretching in aldehyde groups (Table 1).

$\mathrm{FMNs}=$ ferromagnetic nanoparticles; GA = glutaraldehyde; $\mathrm{Ab}=$ antibodies against Salmonella.

Antibodies against the Salmonella spectrum had unique peaks at wave numbers $1655(\mathrm{C}=\mathrm{O}$ stretching vibration of amide I band) and 1544 (N-H bending of amide II). The Salmonella cell had a spectrum with unique peaks at wave numbers $1654 \mathrm{C}=\mathrm{O}$ vibration stretching of amide I, $1544 \mathrm{C}-\mathrm{N}$ stretching and $\mathrm{NH}$ bending vibration of amide II, and 1542 $\mathrm{CH}_{2}$ scissoring vibration.

4.2. Stage II: FMN with Surface Modification and GA Crosslinking. In this experiment, the glutaraldehyde is used as the crosslinker to bind its own aldehyde group to the amine group of FMNs. It was expected that the $\mathrm{CHO}$ group of the other end of GA could also bind to the amine group of antibodies against Salmonella cells [41]. GA is an organic compound that contains a linear set of 5 carbons and dialdehyde groups $(-\mathrm{CHO})$ on both ends. Its chemical formula was $\mathrm{C}_{5} \mathrm{H}_{8} \mathrm{O}_{2}$ or $\mathrm{OHC}\left(\mathrm{CH}_{2}\right)_{3} \mathrm{CHO}$ or $\mathrm{HCO}\left(\mathrm{CH}_{2}\right)_{3} \mathrm{CHO}$ [42]. The functional group of glutaraldehyde contains the aldehyde group (-CHO) and the alkyl group $\left(\mathrm{CH}_{2}\right)$ [43] The main peaks from Synchrotron FTIR spectra of FMNsglutaraldehyde can be assigned as follows: $3356 \mathrm{~cm}^{-1}(\mathrm{O}-\mathrm{H}$ 


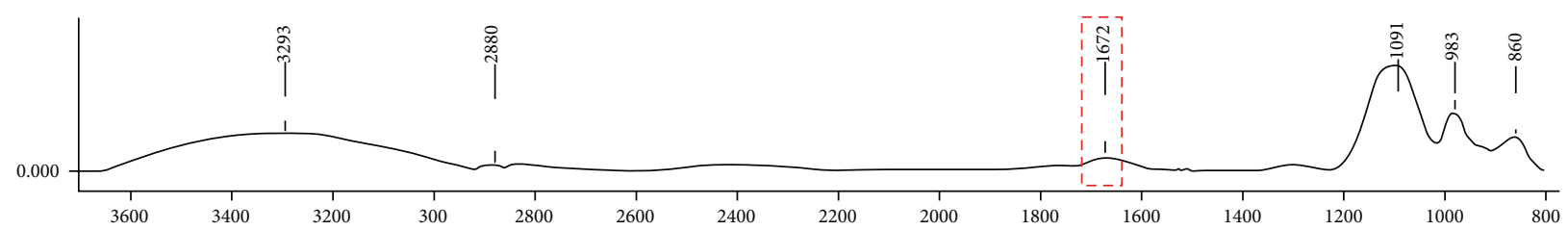

(a)

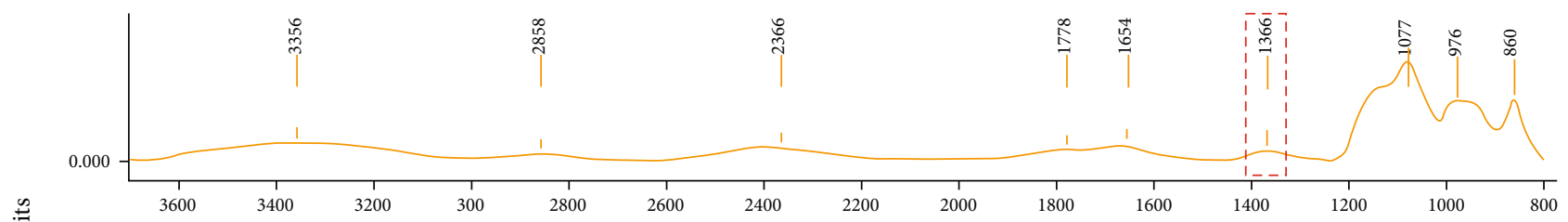

(b)

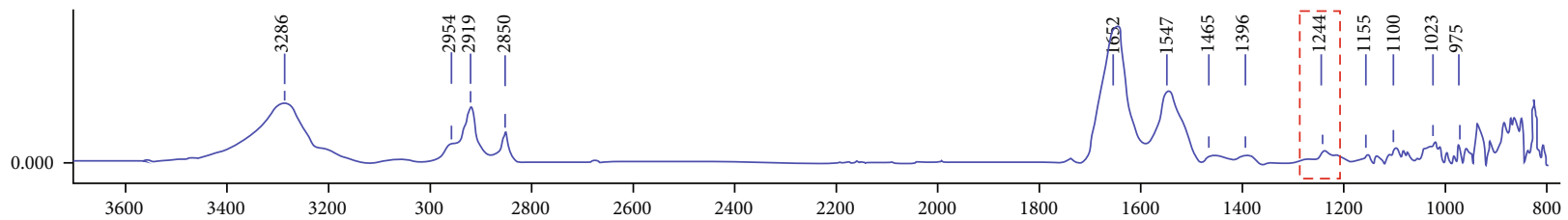

(c)

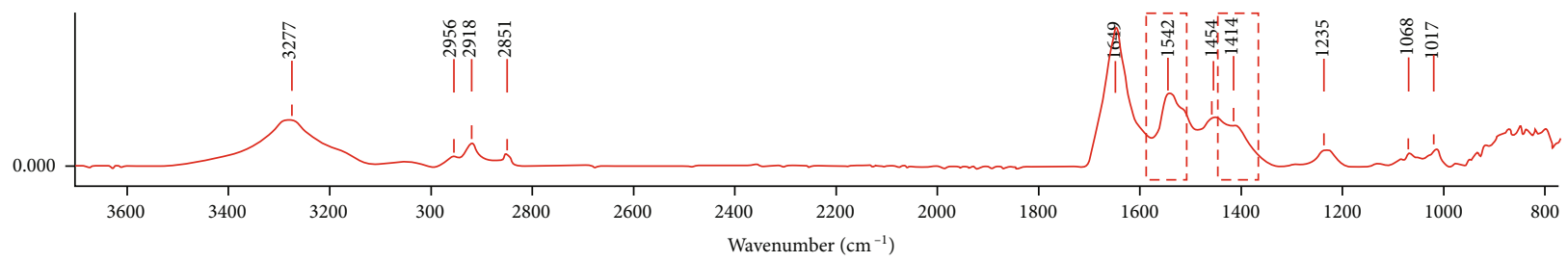

(d)

FIGURE 4: Summary signal changes in each stage tracked with Synchrotron FTIR spectroscopy, (a) amino-FMNs, (b) FMN-GA crosslinking, (c) FMN-GA-Ab, and (d) FMN-GA-Ab-Salmonella, where GA = glutaraldehyde. Boxes indicated unique peaks to represent detection and control peaks. Unique peaks of each step are shown in boxes.

TABLE 1: Matrix table to track signal changes of 4-stage magnetic nanoparticles for culture-independent detection of Salmonella sp.

\begin{tabular}{|c|c|c|c|c|c|c|}
\hline Vibration modes & $\begin{array}{c}\text { Stage } 0 \\
\text { Salmonella sp. }\end{array}$ & GA & $\begin{array}{l}\text { Stage I } \\
\text { FMNs }\end{array}$ & $\begin{array}{c}\text { Stage II } \\
\text { FMNs+GA }\end{array}$ & $\begin{array}{c}\text { Stage III } \\
\text { FMNs+GA+Ab }\end{array}$ & $\begin{array}{c}\text { Stage IV } \\
\text { FMNs+GA+Ab+Salmonella sp. }\end{array}$ \\
\hline $\mathrm{O}-\mathrm{H}$ asymmetric and symmetric stretching & - & - & 3293 & 3356 & - & - \\
\hline $\begin{array}{l}\text { C-H asymmetric and symmetric stretching } \\
\text { vibration }\end{array}$ & 2876 & 2872 & 2881 & 2858 & 2851 & 2851 \\
\hline $\mathrm{C}=\mathrm{O}$ stretching in aldehydes & - & 1772 & - & 1778 & - & - \\
\hline $\mathrm{N}-\mathrm{H}$ bending of $\mathrm{NH}_{2}$ group (scissoring) & - & - & 1673 & - & - & - \\
\hline $\mathrm{C}=\mathrm{N}$ stretching & - & - & - & 1654 & - & - \\
\hline $\mathrm{C}=\mathrm{O}$ stretching vibration of amide $\mathrm{I}$ & 1649 & - & - & - & 1652 & 1649 \\
\hline $\begin{array}{l}\text { C-N stretching and } \mathrm{N}-\mathrm{H} \text { bending vibration } \\
\text { of amide II }\end{array}$ & 1582 & - & - & - & 1547 & 1542 \\
\hline $\mathrm{CH}_{2}$ scissoring & 1451 & 1460 & - & - & - & 1454 \\
\hline $\begin{array}{l}\mathrm{C}=\mathrm{O} \text { symmetric stretching of } \mathrm{COO}^{-} \text {group } \\
\text { in amino acid, fatty acids }\end{array}$ & 1406 & - & - & - & - & 1414 \\
\hline Aldehydic C-H bending vibration & - & - & - & 1366 & - & - \\
\hline $\begin{array}{l}\text { C-N stretching and } \mathrm{N}-\mathrm{H} \text { bending vibration } \\
\text { of amide III }\end{array}$ & - & - & - & - & 1244 & - \\
\hline $\begin{array}{l}\mathrm{P}=\mathrm{O} \text { asymmetric stretching of } \\
\text { phosphodiester in phospholipids }\end{array}$ & 1238 & - & - & - & - & 1235 \\
\hline C-N stretching & - & - & 1090 & 1077 & - & - \\
\hline
\end{tabular}




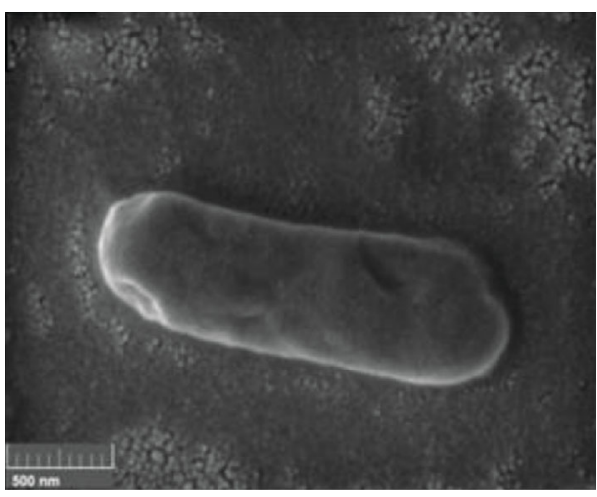

(a)

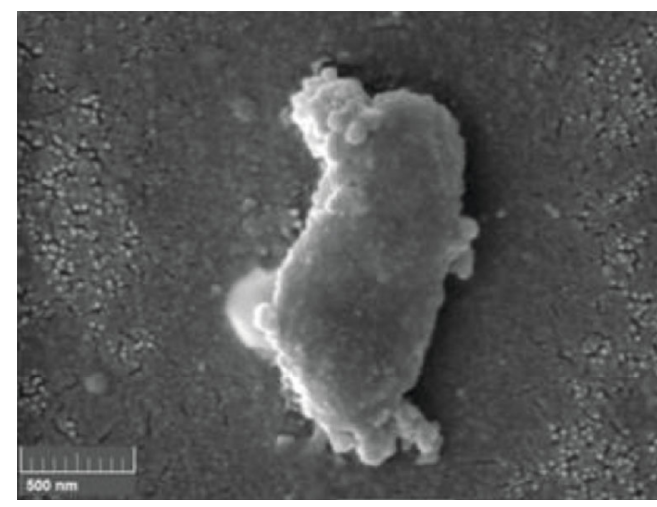

(b)

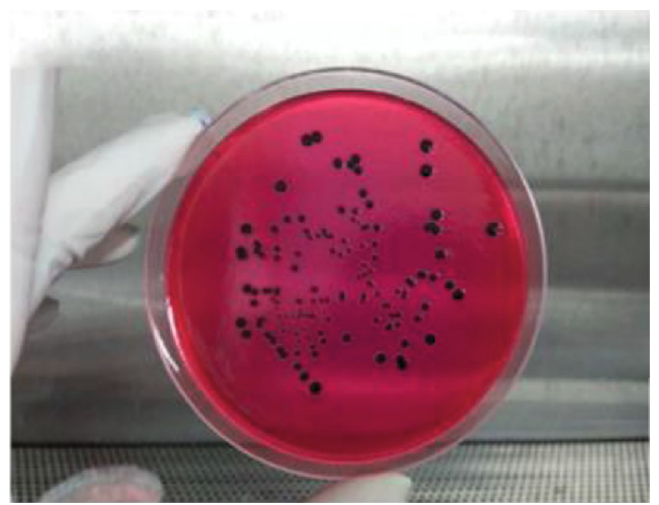

(c)

FIGURE 5: Field emission scanning electron micrograph of Salmonella cell (a) and cell with nanoparticles (b) on their surface. Bars on images were $500 \mathrm{~nm}$. The captured bacteria could grow and express typical colonies on the XLD plate (c).

asymmetric and symmetric stretching) [44], $2858 \mathrm{~cm}^{-1}(\mathrm{C}-\mathrm{H}$ asymmetric and symmetric stretching of $\mathrm{CH}_{2}$ in aliphatic compounds) [39], $1778 \mathrm{~cm}^{-1}$ ( $\mathrm{C}=\mathrm{O}$ stretching in aldehydes) $[39,45], 1654 \mathrm{~cm}^{-1}$ (C=N stretching) [31], $1366 \mathrm{~cm}^{-1}$ (aldehydic $\mathrm{C}-\mathrm{H}$ bending vibration) $[40], 1077 \mathrm{~cm}^{-1}$ (C-N stretching), and $860\left(\mathrm{~N}-\mathrm{H}\right.$ of $\mathrm{NH}_{2}$ out of plane bending) [45]. The characteristic peaks were at 1778 and $1366 \mathrm{~cm}^{-1}$.

In this case, the peak at about $1654 \mathrm{~cm}^{-1}$ was the imine bond $(\mathrm{C}=\mathrm{N})$, which could be ascribed as the product of an interaction between the aldehyde group (-CHO) of the glutaraldehyde and the amino group $[39,43]$. The reaction could lead to the formation of an amide bond as follows [46]:

$$
--\mathrm{NH}_{2}+\mathrm{O}=\mathrm{HC}-\longrightarrow^{\text {yields }}--\mathrm{N}=\mathrm{CN}--
$$

Moreover, the peaks at $2858 \mathrm{~cm}^{-1}$ refer to $\mathrm{C}-\mathrm{H}$ symmetric stretching of $\mathrm{CH}_{2}$ in the aliphatic compound and $1366 \mathrm{~cm}^{-1}$ as aldehydic $\mathrm{C}-\mathrm{H}$ bending vibration. Results indicated that surface modification of FMNs with glutaraldehyde was successful. The peak around $1366 \mathrm{~cm}^{-1}$ was a unique peak of step 2 , which is a characteristic of aldehydic $\mathrm{C}-\mathrm{H}$ bending vibration. The presence of the peak at wave number $1778(\mathrm{C}=\mathrm{O})$ after the attachment indicated the ability to link the FMNsGA to the target antibody in the next step.

4.3. Stage III: FMN-GA with Antibodies ( $A b)$. Antibodies are biopolymers comprised of amino acids with a three- dimensional structure of protein. The structure of antibodies consists of four polypeptide chains linked by disulfide bridges. The backbone of the polypeptide chain includes the atoms of the peptide bonds, $\mathrm{C}=\mathrm{O}, \mathrm{N}-\mathrm{H}$, and the $\alpha$-carbon $[41,47]$. The main peaks from FTIR spectra of FMNs-GA$\mathrm{Ab}$ can be assigned as follows: $3286 \mathrm{~cm}^{-1}$ (N-H stretching of amide A), $2919 \mathrm{~cm}^{-1}$ (C-H asymmetric and symmetric stretching vibration), $2851 \mathrm{~cm}^{-1}$ (C-H asymmetric and symmetric stretching vibration) [39], $1652 \mathrm{~cm}^{-1}$ (C=O stretching vibration of amide I), $1547 \mathrm{~cm}^{-1}(\mathrm{~N}-\mathrm{H}$ bending and $\mathrm{C}-\mathrm{N}$ stretching vibration of amide II) [38], $1465 \mathrm{~cm}^{-1}$ (C-H deformation of $\left.\mathrm{CH}_{3}\right), 1396 \mathrm{~cm}^{-1}\left(\mathrm{C}=\mathrm{O}\right.$ stretching of $\left.\mathrm{COO}^{-}\right)$[39, 48 ], $1244 \mathrm{~cm}^{-1}$ (C-H stretching and $\mathrm{N}-\mathrm{H}$ in plane bending vibration of amide III) [48], $1213 \mathrm{~cm}^{-1}$ (C-C-N bending in amine), and $1017 \mathrm{~cm}^{-1}$ (carbon ring in cyclic compound) breathing [39]. Particularly, peaks at $1652 \mathrm{~cm}^{-1}, 1547 \mathrm{~cm}^{-1}$, and $1244 \mathrm{~cm}^{-1}$ indicate the successful attachment of glutaraldehyde with amine groups onto the surface of FMNs and amine of antibody conjugation forming amide bonding $(\mathrm{CO}-\mathrm{NH})$. The peak at $1244 \mathrm{~cm}^{-1}$ was characterized as a unique peak for control of Stage III. At this step, the aldehyde group at wave number 1778 reacted with the target antibody and, therefore, was not detected at this stage (Table 1).

4.4. Stage IV: FMNs-GA-Antibody Complex with Salmonella Cells. Amino-functionalized ferromagnetic nanoparticles (amino-FMNs) link to the aldehyde group of glutaraldehyde 
crosslink bearing another aldehyde end to link to specific antibodies against Salmonella spp. SR-FTIR spectroscopy provided signal changes during reaction stages on the surface of magnetic nanoparticles attached onto the Salmonella cell surface. In this experiment, the spectra of Salmonella cells were used as the reference. Figure 4 showed unique peaks for the nanoparticles with and without Salmonella at 1454, and $1414 \mathrm{~cm}^{-1}$, which is the mixed region of fatty acid bending vibration, proteins, and phosphate-carrying compounds [16]. Moreover, the peak observed around $1235 \mathrm{~cm}^{-1}$ was a signal of phospholipids, which is based on the biochemical heterogeneity of outer membrane cell components [49], and peak $1068 \mathrm{~cm}^{-1}$ indicated carbohydrate in the bacteria, which is dominated by $\mathrm{C}-\mathrm{O}-\mathrm{C}$ and $\mathrm{C}-\mathrm{O}$ ring vibrations in various polysaccharides [19]. These signals indicated the successful attachment of the magnetic nanoparticle complex on the Salmonella cell surface. Peaks at 1649 and $1542 \mathrm{~cm}^{-1}$ representing amide I band and amide II are also in the region of secondary structure protein in the cell [50], but the region was overlapped with the spectrum of the antibodies and of functionalized FMNs. They were not chosen as unique peaks. The peaks at 1454, and $1414 \mathrm{~cm}^{-1}$ of $\mathrm{CH}_{2}$ scissoring, and $\mathrm{C}=\mathrm{O}$ symmetric stretching of the $\mathrm{COO}^{-}$group in amino acids and fatty acids were chosen as the unique peaks for the attachment of the FMN complex to Salmonella cells. Peaks of Salmonella and FMNs-Salmonella are as shown in Figure 4. In addition, the information of the fatty acid region can be derived from the responsible bands for - $\mathrm{CH}$ deformation in the $1500-1200 \mathrm{~cm}^{-1}$ area. For this experiment, the $\mathrm{P}=\mathrm{O}$ asymmetric stretching at $1238 \mathrm{~cm}^{-1}$ shifted slightly to $1235 \mathrm{~cm}^{-1}$ indicating changes in the phospholipids of nanoparticle-exposed bacteria. Many studies reported that the decrease in peak intensity of phosphate groups was due to the sensitivity of hydration-dehydration of phosphoric groups in lipid structures. This mechanism is responsible for the changes in permeation in terms of the depletion in ATP levels that has been reported as a nanoparticle impact on bacteria [28]. Changes in the protein region in the range of $1800-1500 \mathrm{~cm}^{-1}$ of amide I and amide II of protein and peptide were observed. The amide I band represents $\mathrm{C}=\mathrm{O}$ stretching vibration, and amide II band represents $\mathrm{N}-\mathrm{H}$ bending with contributions from the $\mathrm{C}-\mathrm{N}$ stretching vibrations of the peptide group [32]. In this study, the $\mathrm{C}=\mathrm{O}$ stretching vibration of amide I at $1654 \mathrm{~cm}^{-1}$ shifting to $1649 \mathrm{~cm}^{-1}$ and the amide II at $1544 \mathrm{~cm}^{-1}$ shifting to $1542 \mathrm{~cm}^{-1}$ may signal a change from $\beta$-sheet to a random coil structure [51]. Metal nanoparticles could interact with the protein conformation in nanoparticle-treated bacteria by interacting with thiol groups of respiratory chain enzymes and other amino acid groups of bacteria membranes [28]. Changes in the carbohydrate region were observed between 900 and $1200 \mathrm{~cm}^{-1}$ and the C-O-C and C-O ring vibrations in various polysaccharides in the cell wall [32].

The profiles of polysaccharide bands after treatment with nanoparticles were changed. For this experiment, the peak at $1082 \mathrm{~cm}^{-1}$ disappeared after magnetic nanoparticle attachment with the target Salmonella cells but new bands showed up at $1068 \mathrm{~cm}^{-1}$ and $1017 \mathrm{~cm}^{-1}$. These spectral changes were due to lipopolysaccharide peroxidation of the asymmetric outer membrane, amphipathic molecules, or lipopolysaccharides [28]. From overall results and discussion, the signal changes in each stage are shown in Figure 4 and Table 1.

The attachment of the FMN complex to Salmonella cells was demonstrated as a scanning micrograph of cells with FMNs in Figure 5. The captured cells could survive and produce colonies on xylose lysine desoxycholate agar.

However, many reports indicated that inherent characteristics of nanoparticles could lead to variability of reproducibility and consistency of the results. Surface functionalization of nanoparticles could be inconsistent. Complex particle syntheses could affect size and shape and their characteristics, for example, the surface to volume ratio that affects surface energy, solubility, and agglomeration [52]. An extensive review was made by Baer [53]. Results of X-ray Absorption Spectroscopy (XAS) studies of FMNs, in our laboratory, indicated changes of the electronic structure of FMNs after the attachment to Salmonella cells (data not shown). However, in this study, the FMNs were prepared fresh prior to the experiment. The polyol technique under low heat treatment in an autoclave could control the synthesis condition and produce FMNs with consistent characteristics [11]. The FMNs were stored in an airtight amber bottle to prevent exposure to light and oxygen. FTIR results from duplicated samples of this study appeared to be consistent.

\section{Conclusion}

This work demonstrated tracking of SR-FTIR signal changes of amino-functionalized FMN with GA crosslink, antibodies, and Salmonella cells individually and after reaction steps. Spectra of the controls, FMNs, glutaraldehyde, the antibody against Salmonella, and Salmonella cells alone were identified.

FMNs had a unique peak at wave number 1672 of $\mathrm{NH}$ bending (scissoring). The glutaraldehyde spectrum showed $\mathrm{C}=\mathrm{O}$ stretching in the aldehyde peak at wave number 1722 . Antibody against Salmonella had $\mathrm{C}=\mathrm{O}$ stretching of amide I at $1656 \mathrm{~cm}^{-1}$ and NH-bending of amide II at $1545 \mathrm{~cm}^{-1}$. Salmonella, on the other hand, showed a spectrum of $\mathrm{C}=\mathrm{O}$ stretching vibration of amide I at $1649 \mathrm{~cm}^{-1}$.

Signal changes of each attachment step are as follows. The FMN spectrum at wave number $1673(\mathrm{~N}-\mathrm{H})$ reacted with the aldehyde group $\left(1460 \mathrm{~cm}^{-1}\right)$ of glutaraldehyde. The disappearance of peaks at 1763 and 1460 of FMN-GA proved this attachment. The peak at $1778 \mathrm{~cm}^{-1}$ in this stage indicated the availability of the aldehyde group on the FMN-GA complex. This aldehyde group is available for attachments to $\mathrm{Ab}$ in the next step. The FMNs-GA-Ab spectrum showed peaks at wave number 1244 (C-N stretching) indicating the attachment of the aldehyde group (GA) to an amino group (Ab). No peak at $1788 \mathrm{~cm}^{-1}$ also indicates the remaining aldehyde group attachment on Ab. At the final step, the FMN-GA$\mathrm{Ab}$ complex attached to Salmonella cells. The attachment causes peaks at $1655 \mathrm{~cm}^{-1} \mathrm{C}=\mathrm{O}$ amine $\mathrm{I}$ to react with the $\mathrm{NH}_{2}$ group of $\mathrm{Ab}$ resulting in $\mathrm{CH}_{2}$ scissoring peak at $1454 \mathrm{~cm}^{-1}$. No $1655 \mathrm{~cm}^{-1}$ peak was observed in this step.

The Synchrotron FTIR results revealed that the attachments of magnetic nanoparticles on the Salmonella cell 
surface gave specific peaks at 1542 and $1414 \mathrm{~cm}^{-1}$ of amide II band of protein and $\mathrm{C}=\mathrm{O}$ symmetric stretching of the $\mathrm{COO}^{-}$ group in amino acid or fatty acids, respectively. The bands at $1244 \mathrm{~cm}^{-1}$ and $1454 \mathrm{~cm}^{-1}$ were unique to $\mathrm{Ab}-\mathrm{FMNs}$ without and with the attachment of target cells. The rapid capture/concentration and isolation of the target Salmonella had unique SR-FTIR peaks, which could be used in various applications for rapid detection of target Salmonella and for the design of a generic machine for the rapid, noncontact, nondestructive, and culture-independent detection method/platform of pathogens in food products. The method may be extended to environmental and medical diagnosis in the future.

\section{Data Availability}

The data that support the finding of this study was available on request from the corresponding authors.

\section{Conflicts of Interest}

The authors declare that there is no conflict of interest regarding the publication of this paper.

\section{Acknowledgments}

The research was supported by the Office of Disease Prevention and Control 4, Saraburi; Department of Disease Control, Ministry of Public Health; BL4.1. of the IR-Spectroscopy Synchrotron Light Research Institute (Public Organization); KMUTT Maintenance Technology and Inspection Center; and S\&A Reagents Ltd. which are acknowledged. Financial supports from the National Research Council of Thailand (NRCT), Agricultural Research Development Agency (ARDA), and Food Safety Center of the TISTR, KMUTT, are truly appreciated.

\section{References}

[1] WHO, Salmonella (non-typhoidal)2018, http://www.who.int/ new-room/fact-sheets/detail/salmonella-(non-typhoidal)/en/.

[2] Center for Disease Control, SalmonellaJuly, 2019, https://www. cdc.gov/salmonella/index.html.

[3] European Food Safety Authority and European Centre for Disease Prevention and Control (EFSA and ECDC), "The European Union Summary report on trends and sources of zoonoses, zoonotic agents and food-borne outbreaks in 2017," EFSA Journal, vol. 16, no. 12, 2018.

[4] DDC, Food poisoningJuly 2018, https://ddc.moph.go.th/th/ site/disease/detail/10/status.

[5] N. F. D. Silva, J. M. C. S. Magalhaes, C. Freire, and C. DelerueMatos, "Electrochemical biosensors for Salmonella: State of the art and challenges in food safety assessment," Biosensors and Bioelectronics, vol. 99, pp. 667-682, 2018.

[6] C. Bayraç, F. Eyidoğan, and H. Avni Öktem, "DNA aptamerbased colorimetric detection platform for Salmonella Enteritidis," Biosensors and Bioelectronics, vol. 98, pp. 22-28, 2017.

[7] K.-M. Lee, M. Runyon, T. J. Herrman, R. Phillips, and J. Hsieh, "Review of Salmonella detection and identification methods:
Aspects of rapid emergency response and food safety," Food Control, vol. 47, pp. 264-276, 2015.

[8] C. Almeida, L. Cerqueira, N. F. Azevedo, and M. J. Vieira, "Detection of Salmonella enterica serovar Enteritidis using real time PCR, immunocapture assay, PNA FISH and standard culture methods in different types of food samples," International Journal of Food Microbiology, vol. 161, no. 1, pp. 1622, 2013.

[9] J. K. Xu, F. F. Zhang, J. J. Sun, J. Sheng, F. Wang, and M. Sun, "bio and nanomaterials based on $\mathrm{Fe}_{3} \mathrm{O}_{4}$," Molecules, vol. 19, no. 12, pp. 21506-21528, 2014.

[10] K. Niemirowicz, K. H. Markiewicz, A. Z. Wilczewska, and H. Car, "Magnetic nanoparticles as new diagnostic tools in medicine," Advances in Medical Sciences, vol. 57, no. 2, pp. 196-207, 2012.

[11] N. Songvorawit, K. Tuitemwong, and P. Tuitemwong, "Single Step Synthesis of Amino-Functionalized Magnetic Nanoparticles with Polyol Technique at Low Temperature," ISRN Nanotechnology, vol. 2011, 6 pages, 2011.

[12] M. Mahdavi, M. Ahmad, M. Haron et al., "Synthesis, surface modification and Characterisation of biocompatible magnetic iron oxide nanoparticles for biomedical applications," Molecules, vol. 18, no. 7, pp. 7533-7548, 2013.

[13] Q. Sun, G. Zhao, and W. Dou, "An optical and rapid sandwich immunoassay method for detection of Salmonella pullorum and Salmonella gallinarum based on immune blue silica nanoparticles and magnetic nanoparticles," Sensors and Actuators B: Chemical, vol. 226, pp. 69-75, 2016.

[14] K. Ma, Y. Deng, Y. Bai et al., "Rapid and simultaneous detection of Salmonella, Shigella, and Staphylococcus aureus in fresh pork using a multiplex real-time PCR assay based on immunomagnetic separation," Food Control, vol. 42, pp. 87-93, 2014.

[15] P. Tuitemwong, N. Songvorawit, and K. Tuitemwong, "Facile and Sensitive Epifluorescent Silica Nanoparticles for the Rapid Screening of EHEC," Journal of Nanomaterials, vol. 2013, 8 pages, 2013.

[16] W. Poonlapdecha, Y. Seetang-Nun, W. Wonglumsom et al., "Antibody-conjugated ferromagnetic nanoparticles with lateral flow test strip assay for rapid detection of Campylobacter jejuni in poultry samples," International Journal of Food Microbiology, vol. 286, pp. 6-14, 2018.

[17] K. Carlson, M. Misra, and S. Mohanty, "Developments in micro- and nanotechnology for foodborne pathogen detection," Foodborne Pathogens and Disease, vol. 15, no. 1, pp. 16-25, 2018.

[18] M. A. Ali, T. A. Salah Eldin, G. M. MoghazyEl, I. M. Tork, and I. I. Omara, "Detection of E.coli O157:H7 in feed samples using gold nanoparticles sensor," International Journal of Current Microbiology and Applied Sciences, vol. 3, no. 6, pp. 697708, 2014.

[19] R. Davis and L. J. Mauer, "Fourier transformed infrared (FT-IR) spectroscopy: a rapid tool for detection and analysis of foodborne pathogenic bacteria," in Current Research, Technology and Education Topics in Applied Microbiology and Microbial Biotechnology, A. Méndez-Vilas, Ed., vol. 2, pp. 1582-1594, Department of Food Science, Purdue University, 745 Agriculture Mall Drive, West Lafayette, Indiana, 2010.

[20] N. Buensanteai, K. Thumanu, M. Sompong, D. Athinuwat, and S. Prathuangwong, "The FTIR spectroscopy investigation of the cellular components of cassava after sensitization with plant growth promoting rhizobacteria, Bacillus subtilis 
CaSUT007," African Journal of Microbiology Research, vol. 6, no. 3, pp. 603-610, 2012.

[21] C. Carlos, D. A. Maretto, R. J. Poppi, M. I. Z. Sato, and L. M. M. Ottoboni, "Fourier transform infrared microspectroscopy as a bacterial source tracking tool to discriminate fecal E. coli strains," Microchemical Journal, vol. 99, no. 1, pp. 15-19, 2011.

[22] A. D. Gupta and S. Karthikeyan, "Individual and combined toxic effect of nickel and chromium on biochemical constituents in E. coli using FTIR spectroscopy and Principle component analysis," Ecotoxicology and Environmental Safety, vol. 130, pp. 289-294, 2016.

[23] J. Kong and S. Yu, "Fourier transform infrared spectroscopic analysis of protein secondary structures," Acta Biochimica et Biophysica Sinica, vol. 39, no. 8, pp. 549-559, 2007.

[24] K. Thumanu, S. Sangrajrang, T. Khuhaprema et al., "Diagnosis of liver cancer from blood sera using FTIR microspectroscopy: a preliminary study," Journal of Biophotonics, vol. 7, no. 3-4, pp. 222-231, 2014.

[25] A. C. S. Talari, M. A. G. Martinez, Z. Movasaghi, S. Rehman, and I. U. Rehman, "Advances in Fourier transform infrared (FTIR) spectroscopy of biological tissues," Applied Spectroscopy Reviews, vol. 52, no. 5, pp. 456-506, 2016.

[26] V. Erukhimovitch, V. Pavlov, M. Talyshinsky, Y. Souprun, and M. Huleihel, "FTIR microscopy as a method for identification of bacterial and fungal infections," Journal of Pharmaceutical and Biomedical Analysis, vol. 37, no. 5, pp. 1105-1108, 2005.

[27] I. J. Mauer, B. L. Reuhs, and J. G. Voeller, "Mid-infrared sensors for the rapid analysis of select microbial foodborne pathogens," in Wiley Handbook of Science and Technology for Homeland Security, J. G. Voeller, Ed., Wiley, London, 2008.

[28] F. Faghihzadeh, N. M. Anaya, L. A. Schifman, and V. Oyanedel-Craver, "Fourier transform infrared spectroscopy to assess molecular-level changes in microorganisms exposed to nanoparticles," Nanotechnology for Environmental Engineering, vol. 1, no. 1, 2016.

[29] D. Naumann, D. Helm, and H. Labischinski, "Microbiological characterizations by FT-IR spectroscopy," Nature, vol. 351, no. 6321, pp. 81-82, 1991.

[30] G. Kosa, V. Shapaval, A. Kohler, and B. Zimmermann, "FTIR spectroscopy as a unified method for simultaneous analysis of intra- and extracellular metabolites in high-throughput screening of microbial bioprocesses," Microbial Cell Factories, vol. 16, no. 1, p. 195, 2017.

[31] K. Maquelin, C. Kirschner, L. P. Choo-Smith et al., "Prospective study of the performance of vibrational spectroscopies for rapid identification of bacterial and fungal pathogens recovered from blood cultures," Journal of Clinical Microbiology, vol. 41, no. 1, pp. 324-329, 2003.

[32] Y.-D. Wang, X.-L. Li, Z.-X. Liu, X.-X. Zhang, J. Hu, and J.-H. Lü, "Discrimination of foodborne pathogenic bacteria using synchrotron FTIR microspectroscopy," Journal of Nuclear Science and Technology, vol. 28, no. 4, 2017.

[33] N. S. K. Gunda, M. Singh, L. Norman, K. Kaur, and S. K. Mitra, "Optimization and characterization of biomolecule immobilization on silicon substrates using (3-aminopropyl) triethoxysilane (APTES) and glutaraldehyde linker," Applied Surface Science, vol. 305, pp. 522-530, 2014.

[34] Z. Wang, T. Yue, Y. Yuan, R. Cai, C. Niu, and C. Guo, "Preparation of immunomagnetic nanoparticles for the separation and enrichment of Alicyclobacillus spp. in apple juice," Food Research International, vol. 54, no. 1, pp. 302-310, 2013.
[35] D. Naumann, "Infrared spectroscopy in microbiology," in Encyclopedia of Analytical Chemistry, R. A. Meyers, Ed., pp. 102-131, John Wiley \& Sons, Ltd, Chichese, UK, 2000.

[36] W. Jiang, A. Saxena, B. Song, B. B. Ward, T. J. Beveridge, and S. C. B. Myneni, "Elucidation of functional groups on Grampositive and Gram-negative bacterial surfaces using infrared spectroscopy," Langmuir, vol. 20, no. 26, pp. 11433-11442, 2004.

[37] K. Phalang and S. Chaichanakun, Organic Chemistry (7th ed.), Chulalongkorn University Press, Chulalongkorn, 2014.

[38] T. Q. Huy, N. T. H. Hanh, P. van Chung, D. D. Anh, P. T. Nga, and M. A. Tuan, "Characterization of immobilization methods of antiviral antibodies in serum for electrochemical biosensors," Applied Surface Science, vol. 257, no. 16, pp. 70907095, 2011.

[39] H. F. Shurvell, "Spectra-structure correlation in the mid-and far-infrared," in Handbook of Vibration Spectroscopy Volume 3, J. M. Chalmers and P. R. Griffiths, Eds., pp. 1791-1793, John Wiley \& Sons Ltd, Chichester, 2002.

[40] R. M. Silverstein, F. X. Webster, and D. J. Kiemle, Spectrometric Identification of Organic Compounds, John Wiley \& Sons, Inc., 7th ed edition, 2005.

[41] M. Shen, J. F. Rusling, and C. K. Dixit, "Site-selective orientated immobilization of antibodies and conjugates for immunodiagnostics development," Methods, vol. 116, pp. 95-111, 2017.

[42] I. Migneault, C. Dartiguenave, M. J. Bertrand, and K. C. Waldron, "Glutaraldehyde: behavior in aqueous solution, reaction with proteins, and application to enzyme crosslinking," BioTechniques, vol. 37, no. 5, pp. 790-802, 2004.

[43] C. B. Fryhle, S. A. Snyder, and T. W. G. Solomons, Organic Chemistry, John Wiley \&Sons, Inc., 2018.

[44] T. Mitra, G. Sailakshmi, and A. Gnanamani, "Could glutaric acid (GA) replace glutaraldehyde in the preparation of biocompatible biopolymers with high mechanical and thermal properties?," Journal of Chemical Sciences, vol. 126, no. 1, pp. 127-140, 2014.

[45] B. Grabowska, M. Sitarz, E. Olejnik, and K. Kaczmarska, "FTIR and FT-Raman studies of cross-linking processes with $\mathrm{Ca} 2$ + ions, glutaraldehyde and microwave radiation for polymer composition of poly(acrylic acid)/sodium salt of carboxymethyl starch - part I," Spectrochimica Acta Part A: Molecular and Biomolecular Spectroscopy, vol. 135, pp. 529-535, 2015.

[46] M. Rani, A. Agarwal, and Y. S. Negi, "Characterization and biodegradation studies for interpenetrating polymeric network (IPN) of chitosan-amino acid beads," Journal of Biomaterials and Nanobiotechnology, vol. 2, no. 1, pp. 71-84, 2011.

[47] N. G. Welch, J. A. Scoble, B. W. Muir, and P. J. Pigram, "Orientation and characterization of immobilized antibodies for improved immunoassays (review)," Biointerphases, vol. 12, no. 2, p. 02D301, 2017.

[48] P. Garidel and H. Schott, "Fourier-transform mid-infrared spectroscopy for analysis and screening of liquid protein formulations," BioProcess International, vol. 4, no. 6, pp. 48-55, 2006.

[49] S. Kim, H. Kim, B. L. Reuhs, and L. J. Mauer, "Differentiation of outer membrane proteins from Salmonellaenterica serotypes using Fourier transform infrared spectroscopy and chemometrics," Letters in Applied Microbiology, vol. 42, no. 3, pp. 229-234, 2006.

[50] S. P. Ravindranath, L. J. Mauer, C. Deb-Roy, and J. Irudayaraj, "Biofunctionalized magnetic nanoparticle integrated mid- 
infrared pathogen sensor for food matrixes," Analytical Chemistry, vol. 81, no. 8, pp. 2840-2846, 2009.

[51] S. J. Parikh and J. Chorover, "ATR-FTIR spectroscopy reveals bond formation during bacterial adhesion to iron oxide," Langmuir, vol. 22, no. 20, pp. 8492-8500, 2006.

[52] M. F. Hochella Jr., "Nanoscience and technology: the next revolution in the Earth sciences," Earth and Planetary Science Letters, vol. 203, no. 2, pp. 593-605, 2002.

[53] D. R. Baer, "The Chameleon Effect: Characterization Challenges Due to the Variability of Nanoparticles and Their Surfaces," Frontiers in Chemistry, vol. 6, 2018. 